\title{
REFERENCES
}

Bakermans, W. A. P. and G. Hamming: Onderzoek naar de factoren, die rendabele bietenverbouw op onze zandgronden beperken. Versl. Landbk. Onderz. no. 61.14, 1955.

Ferrari, Th. J., R. P. H. P. van der Schans and F. Sonnevet.d : Het verband tussen de opbrengst (haver en grasland) en de aan de hand van enkelvoudige profielkenmerken geschatte hoeveelheid beschikbaar vocht. Landbouwk. Tiidschr. 1957.

- - and C. M. J. Suuijsmans: Mottling and magnesium deficiency in oats and their dependence on various factors. Plant and Soil VI, 1955, 262-299.

Hotelling, H. : Analysis of a complex of statistical variables into principal components. Journal of Educational Psychology, XXIV, 1933.

KeMr, A.: Welk percentage maakt de eerste snede uit van de totale jaaropbrengst van ons grasland. Verslag C.I.L.O. over 1952, 96-100.

Uppsala Symposium on Psychological Factor Analysis, 17-19 March 1953. Nordisk Psykologi's Monograph Series, No. 3, 1953.

Thurstone, L. L. : Multiple-factor analysis, Chicago, 1950.

VRuES, D. M. DE: Ecological results obtained by the use of interspecific correlation. European Grassland Conference, Paris, 1954.

\section{THE STANDARD DEVIATION IN SOIL TESTING DUE TO WORKING IN SEVERAL LABORATORIES ${ }^{1}$ )}

\author{
F. H. B. VERMEULEN
}

Laboratory for Soil and Crop Testing, Oosterbeek, Holland

The Institution for the Deployment of the Laboratory for Soil and Crop Testing has at its disposal four laboratories located at Oosterbeek, Groningen, Geldrop and Goes. These laboratories test soil samples on behalf of farmers and market gardeners in the Netherlands, the object being to assess the state of fertilisation of the soil and to determine quantitatively fertiliser requirements.

The tests undertaken mainly comprise the following:

a Determining the $\mathrm{pH}$ of the soil. The so-called $\mathrm{pH}-\mathrm{KCl}$ is determined in a suspension of soil in $1 \mathrm{n} \mathrm{KCl}$. This $\mathrm{pH}-\mathrm{KCl}$ constitutes a better basis for advice on liming than does the $\mathrm{pH}$ of a soil and water suspension (VERMeUlen, 1952).

b Determining the organic matter content of the soil. In the case of sandy soils and grassland on clayey soil the organic matter content is determined by the loss on ignition method; in the case of arable land on a clayey soil, by the IsTsCHEREKov method (oxidation with potassium permanganate). The organic matter content serves as an auxiliary quantity in determining the soil's requirements of lime, potash and magnesia fertilisers.

c Determining the clay particle content $(<16$ micron) by the RoBinson pipette method. The clay particle content is an auxiliary quantity in determining the fertiliser requirement.

1) Received for publication March 16, 1957. 
d The calcium carbonate content. The carbonate content is determined by shaking the soil with hydrochloric acid and measuring the quantity of carbon dioxide formed.

e The phosphate content. After extracting the soil with a 1\% citric acid solution the quantity of $\mathrm{P}_{2} \mathrm{O}_{5}$ in the extract is determined by colorimetric analysis (De Vries and Dechering, 1948).

f The potash content. After extracting the soil with $0.1 \mathrm{n}$ hydrochloric acid the quantity of $\mathrm{K}_{2} \mathrm{O}$ in the extract is determined by a flame-photometer (De Vries and Dechering, 1948).

$\mathrm{g}$ The magnesia content. After extracting the soil with a $0.5 \mathrm{n} \mathrm{NaCl}$ solution the quantity of $\mathrm{MgO}$ in the extract is determined by colorimetric analysis.

Using as a basis the figures found at the laboratory, advice on fertilisation is given by the Government Agricultural and Horticultural Information Service to persons sending on soil samples.

The laboratory work is carried out by female laboratory assistants who have usually received a secondary or trade school education. They are trained for this work at the laboratory. Working with this type of staff requires an extensive system of checking (VERMEULEN, 1953).

Routine testing has its own problems and there are many factors that influence the accuracy of the work.

The manner in which the assistants work varies not only according to the time of year (Vermeulen, 1953) but also from day to day (Vermeulen, 1956).

The checking system used includes the testing of a series of control samples of soil examined monthly at the four laboratories.

These soil samples are intensively homogenised at a central point and then distributed over the laboratories.

The results of the analyses are statistically treated and afford an insight into the reproducibility of the determinations. A standard deviation can be calculated from the analysis figures which is an index of the effect of the "fluctuations between the laboratories" on the accuracy of the work. This standard deviation is calculated as :

$$
\mathrm{S}=\sqrt{\frac{\text { sum of } \mathrm{d}^{2}}{\mathrm{~N}-1}}
$$

in which $d$ denotes the differences between the analysis figures found per laboratory and the mean value for the four laboratories, and $\mathrm{N}$ the number of differences.

The standard deviation calculated in this way is composed of the error due to fluctuations between the laboratories, and the error due to carrying out the analyses per laboratory.

It is possible to calculate the latter error as the analyses are carried out in duplicate at each laboratory. The calculation is made in the form of :

$$
\mathrm{S}=\sqrt{\frac{\text { sum of } \mathrm{d}^{2}}{2 \mathrm{~N}}}
$$

in which $\mathrm{d}$ denotes the differences between the two values of the duplicate determination, and $\mathrm{N}$ the number of differences. If the total standard deviation is denoted by the symbol $S_{t}$ and the part due to carrying out the 
analysis per laboratory by $S_{a}$, then the part due to working at different laboratories $\left(\mathrm{S}_{\mathrm{s}}\right)$ may be calculated in the form of:

$$
\mathrm{S}_{\mathrm{s}}=\sqrt{\mathrm{S}_{\mathrm{t}}^{2}-\mathrm{S}_{\mathrm{a}}^{2}}
$$

Only when it is found that $S_{s}$ is equal to zero, i.e. when $S_{t}$ is equal to $S_{a}$, would it be permissible to infer that the "situation" of the laboratory has no effect on the analysis figures to be found. $S_{a}$ has the same value for all laboratories. By the "situation" of the laboratory is meant the complex of factors affecting the analyses, disregarding such effects as may be of influence inside one specific laboratory, e.g. climatic conditions and the humidity of the air in particular. The following shows that the laboratory's "situation" may be quite an appreciable factor.

The magnitude of the standard deviation depends on the magnitude of the analysis figure. Figure 1 represents the standard deviation calculated for different phosphate contents. In addition to the dependence on the content, it is noticeable that the total standard deviation $\left(\mathrm{S}_{\mathrm{t}}\right)$ is greater than the standard deviation per laboratory $\left(S_{a}\right)$.

The effect of the situation of the laboratory $\left(\mathrm{S}_{\mathrm{s}}\right)$ is also shown in Figure 1.

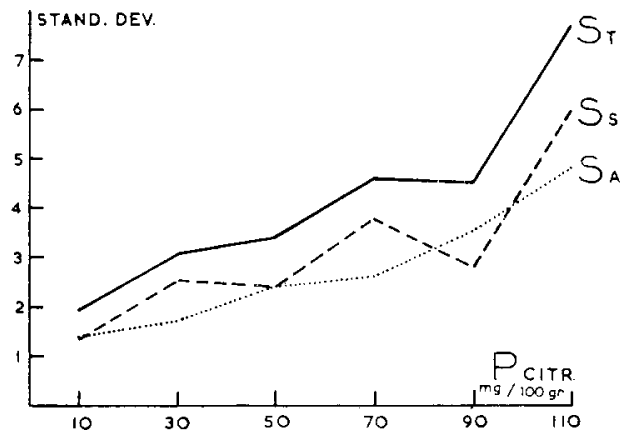

Fig. 1 Dependence of the standard deviation on the phosphate content in a single DETERMTNATION OF TIE PHOSPHATE CONTENT OF SOIL,

$\mathrm{S}_{\mathbf{t}}=$ total standard deviation.

$S_{\mathrm{s}}=$ standard deviation due to the situation of the laboratory.

$S_{a}=$ standard deviation due to the analysis inside a specific laboratory.

In the case of the determination methods mentioned at the beginning of this article the various standard deviations are calculated in the manner described. The results of these calculations are shown in Table 1, the standard deviations always being calculated for the totality. This is relevant in the present case because the total standard deviation and the standard deviation within a specific laboratory are calculated from analyses carried out in the same series of soil samples.

In order to assess the reliability of the standard deviations calculated and to evaluate the significance of the differences between them the standard deviations of the standard deviations are also shown in Table 1. 
Table 1 The standard deviations in various methods of analysis :

$S_{t}=$ total standard deviation.

$S_{\mathrm{s}}=$ standard deviation due to the "situation" of the laboratory,

$S_{\mathbf{a}}=$ standard deviation due to the analysis within a specific laboratory (for the average of a duplicate determination).

\begin{tabular}{|c|c|c|c|c|}
\hline \multirow{2}{*}{ Determination } & \multirow{2}{*}{$\begin{array}{l}\text { Standard deviation } \\
\text { expressed as }\end{array}$} & $\mathrm{S}_{\mathrm{t}}$ & \multirow{2}{*}{$\frac{\mathrm{S}_{\mathrm{s}}}{\begin{array}{c}\text { standard } \\
\text { deviation }\end{array}}$} & \multirow{2}{*}{$\frac{S_{a}}{\begin{array}{c}\text { standard } \\
\text { deviation }\end{array}}$} \\
\hline & & $\begin{array}{l}\text { standard } \\
\text { deviation }\end{array}$ & & \\
\hline $\mathrm{pH}-\mathrm{KCl}$ & $\mathrm{pH}$ units & $0.074 \pm 0.001$ & $0.084+0.001$ & $0.036 \pm 0.001$ \\
\hline Org. matter (loss & $\%$ hur & $0.40 \pm 0.01$ & $0.36 \pm 0.01$ & $0.18 \pm 0.01$ \\
\hline Org. matter (wet oxidation). & $\%$ humus & $0.16 \pm 0.01$ & $0.13 \pm 0.01$ & $0.09 \pm 0.003$ \\
\hline Calcium carbonate ....... & $\% \mathrm{CaCO}_{3}$ & $0.23 \pm 0.01$ & $0.20 \pm 0.01$ & $0.11 \pm 0.005$ \\
\hline Clay content..... & $\%$ clay & $1.02 \pm 0.05$ & $0.87 \pm 0.04$ & $0.53 \pm 0.02$ \\
\hline Phosphate content & $\mathrm{mg} \mathrm{P}_{2} \mathrm{O}_{5} / 100 \mathrm{~g}$ & $2.69 \pm 0.07$ & $2.16 \pm 0.06$ & $1.60 \pm 0.04$ \\
\hline Potash content .. & $\mathrm{mg} \mathrm{K}_{2} \mathrm{O} / 100 \mathrm{~g}$ & $1.81 \pm 0.05$ & $1.32 \pm 0.04$ & $1.24 \pm 0.02$ \\
\hline Magnesia content & $\mathrm{mg} \mathrm{MgO} / \mathrm{kg}$ & $10.5 \pm 0.4$ & $9.5 \pm 0.4$ & $4.5 \pm 0.2$ \\
\hline
\end{tabular}

In order to give an idea of their effect on the accuracy with which advice on fertilisation may be given, the standard deviations are shown in Table 2 as percentages of the contents which are important from the point of view of agriculture.

Table 2 The standard deviations expressed in percentages of contents important from the agricultural point of view.

\begin{tabular}{|c|c|c|c|c|c|}
\hline Determination & $\begin{array}{l}\text { Content to which the } \\
\text { standard deviation } \\
\text { is related }\end{array}$ & & $S_{t}$ & $\mathrm{~S}_{\mathrm{s}}$ & $S_{a}$ \\
\hline $\begin{array}{l}\text { pH-KCl } \ldots \ldots \ldots \ldots \ldots \\
\text { Org. matter (loss on ignition) } \\
\text { Org. matter (wet oxidation) } \\
\text { Calcium carbonate } \ldots \ldots \ldots \\
\text { Clay content } \ldots \ldots \ldots \ldots \\
\text { Phosphate content } \ldots \ldots \ldots \\
\text { Potash content } \ldots \ldots \ldots \ldots \\
\text { Magnesia content } \ldots \ldots \ldots \ldots\end{array}$ & $\begin{array}{c}- \\
8 \% \\
3 \% \\
2 \% \\
40 \% \\
40 \% \mathrm{mg} \mathrm{P}_{2} \mathrm{O}_{5} / 100 \mathrm{~g} \\
50 / 100 \mathrm{~g} \\
30 \mathrm{mg} \mathrm{K} \mathrm{K}_{2} \mathrm{O} / 1 / \mathrm{kg}\end{array}$ & $\begin{array}{c}\text { Absolute } \\
\text { In percentages }\end{array}$ & $\begin{array}{l}0.074 \\
3.2 \\
5.8 \\
4.1 \\
5.1 \\
4.8 \\
4.7 \\
9.4\end{array}$ & $\begin{array}{l}0.064 \\
2.8 \\
4.9 \\
3.7 \\
4.6 \\
3.4 \\
3.6 \\
8.9\end{array}$ & $\begin{array}{l}0.036 \\
1.5 \\
3.1 \\
1.8 \\
2.1 \\
3.4 \\
3.0 \\
3.1\end{array}$ \\
\hline
\end{tabular}

For a proper evaluation of the effect of the various standard deviations on the accuracy of the soil tests their relationship should be compared in quadratic form, since the total standard deviation is, in fact, calculated in the form of

$$
\mathrm{S}_{\mathrm{t}}=\sqrt{\mathrm{S}_{\mathrm{a}}^{2}+\mathrm{S}_{\mathrm{s}}^{2}}
$$

In Figure 2 the quadrated standard deviations are shown as a percentage of $S_{t}{ }^{2}$. In the case of each method of analysis $S_{t}{ }^{2}$ is thus given the value 100 , this facilitating the comparison of the composition of the standard deviations of the various methods. 


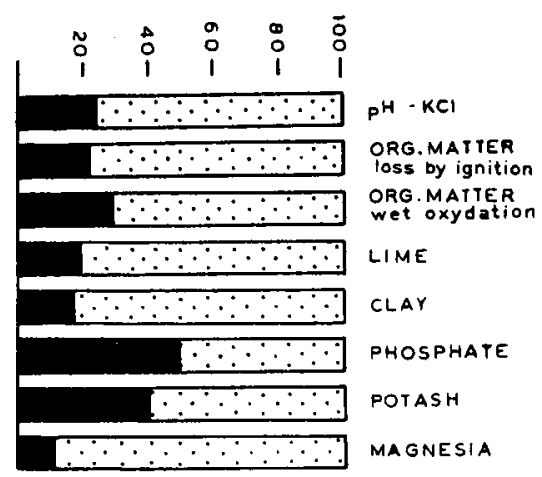

Fig. 2 Composition of the Standard deviation IN MEthods of SOIL testing.

It should be emphasised that when a sample is taken in the field an error is made which considerably exceeds the error made in the laboratory test (FerRari and VermeUlen, 1955).

When the duplicate determinations are carried out in a given laboratory at yearly intervals, for example, the standard deviation is greater than if the duplicate analyses had been made at intervals of a day or a few days.

A part of the fluctuations found between different labaratories is therefore also a factor within one laboratory because after a year other persons may be engaged on the determination who employ other apparatus, and the climatic conditions may also be entirely different.

Thus what has been said above is no argument for centralising the research carried out at a laboratory. On the contrary, the very fact that work was done in several laboratories provides a method of detecting and demonstrating sources of error so that it is now known what matters required attention in order to improve methods.

\section{REFERENCES}

Ferrari, Th. J. en F. H. B. Vermeulen: De betrouwbaarheid van het grondonderzoek, in het bijzonder onder invloed van de ongelijkmatigheid van de grond. Landbouwvoorlichting 12. 9 (Sept. 1955) 389-399.

Vermeulen, F. H. B.: De bepaling van de $\mathrm{pH}$ in de grond. Landbouwk. Tijdschr. 64. 11 (Nov. 1952) 785-788.

- - : Control of the reproducibility and accuracy of routine analyses at the laboratory for Soil and Crop Testing in the Netherlands. Plant and Soil IV. 3 (Jan. 1953) 267-275.

- - : Iets over Foutenanalyse. T.N.O.-Nieuws 8. 82 (Febr. 1953).

-- : De nauwkeurigheid van de bepaling van het kaligehalte in grondmonsters. T.N.O.Nieuws 11. 128 (November 1956).

Vries, O. DE en F. J. A. Dechering : Grondonderzoek, 3rd ed. Published by Hoitsema, Groningen (1948). 